\title{
Article \\ Influence of Different Nanometals Implemented in PMMA Bone Cement on Biological and Mechanical Properties
}

\author{
Beata Świeczko-Żurek ${ }^{1, *}$, Andrzej Zieliński ${ }^{1}{ }^{1}$, Dorota Bociąga ${ }^{2}{ }^{\circledR}$, Karolina Rosińska $^{2}$ and Grzegorz Gajowiec ${ }^{1}$ \\ 1 Faculty of Mechanical Engineering and Ship Technology, Gdańsk University of Technology, \\ 11/12 Narutowicza Str., 80-233 Gdańsk, Poland; andrzej.zielinski@pg.edu.pl (A.Z.); \\ grzgajow@pg.edu.pl (G.G.) \\ 2 Division of Biomedical Engineering and Functional Materials, Institute of Materials Science and Engineering, \\ Lodz University of Technology, 1/15 Stefanowskiego Str., 90-537 Lodz, Poland; \\ dorota.bociaga@p.lodz.pl (D.B.); karolina.rosinska@dokt.p.lodz.pl (K.R.) \\ * Correspondence: beata.swieczko-zurek@pg.edu.pl
}

Citation: Świeczko-Żurek, B.; Zieliński, A.; Bociąga, D.; Rosińska, K.; Gajowiec, G. Influence of Different Nanometals Implemented in PMMA Bone Cement on Biological and Mechanical Properties. Nanomaterials 2022, 12, 732. https:// doi.org/10.3390/nano12050732

Academic Editor: Eleonore Fröhlich

Received: 5 November 2021

Accepted: 11 February 2022

Published: 22 February 2022

Publisher's Note: MDPI stays neutral with regard to jurisdictional claims in published maps and institutional affiliations.

Copyright: (C) 2022 by the authors. Licensee MDPI, Basel, Switzerland. This article is an open access article distributed under the terms and conditions of the Creative Commons Attribution (CC BY) license (https:// creativecommons.org/licenses/by/ $4.0 /)$.

\begin{abstract}
Cemented arthroplasty is a common process to fix prostheses when a patient becomes older and his/her bone quality deteriorates. The applied cements are biocompatible, can transfer loads, and dampen vibrations, but do not provide antibacterial protection. The present work is aimed at the development of cement with antibacterial effectivity achieved with the implementation of nanoparticles of different metals. The powders of $\mathrm{Ag}$, $\mathrm{Cu}$ with particles size in a range of 10-30 nm (Cu10) and 70-100 nm (Cu70), AgCu, and Ni were added to PMMA cement. Their influence on compression strength, wettability, and antibacterial properties of cement was assessed. The surface topography of samples was examined with biological and scanning electron microscopy. The mechanical properties were determined by compression tests. A contact angle was observed with a goniometer. The biological tests included an assessment of cytotoxicity (XTT test on human cells Saos-2 line) and bacteria viability exposure (6 months). The cements with Ag and Cu nanopowders were free of bacteria. For $\mathrm{AgCu}$ and Ni nanoparticles, the bacterial solution became denser over time and, after 6 months, the bacteria clustered into conglomerates, creating a biofilm. All metal powders in their native form in direct contact reduce the number of eukaryotic cells. Cell viability is the least limited by Ag and $\mathrm{Cu}$ particles of smaller size. All samples demonstrated hydrophobic nature in the wettability test. The mechanical strength was not significantly affected by the additions of metal powders. The nanometal particles incorporated in PMMA-based bone cement can introduce longterm resistance against bacteria, not resulting in any serious deterioration of compression strength.
\end{abstract}

Keywords: bone cement; PMMA; nanosilver; nanocopper; nanonickel; antibacterial resistance; cytotoxicity; compression strength; wettability

\section{Introduction}

\subsection{Characteristics of Bone Cements}

The bone cements are usually divided into acrylic and phosphate-based cements [1-4]. Polymethyl methacrylate (PMMA), commonly known as bone cement, is widely used for implant fixation in various orthopedic and trauma surgery. In reality, "cement" is a misnomer because the word "cement" is used to describe a substance, that bonds two things together. However, PMMA acts as a space-filler, that creates a tight space, which holds the implant in contact with the bone. Bone cements have no intrinsic adhesive properties, but they rely instead on a close mechanical interlock between the irregular bone surface and the prosthesis [5]. Adhesion improvement of 50\% at the PMMA bone cement-titanium implant interface was obtained using atmospheric pressure plasma polymerization [6]. As concerns the phosphate-based cements, which usually are applied as bone-substitute materials, recently the brushite-based and monetite-based cements $[1,7,8]$, those based on 
phosphate with bioactive ions, like $\mathrm{Mg}, \mathrm{Sr}, \mathrm{Zn}, \mathrm{Mn}, \mathrm{Cu}, \mathrm{Li}, \mathrm{Co}, \mathrm{Ag}$, [9], and silicate bone cements were proposed.

PMMA bone cements are two-component materials-powder (monomer) and liquid (hardener). After mixing these two components, they polymerize [10]. The polymerization process is accompanied by the release of heat, and as a result, the cement temperature can rise to even $96{ }^{\circ} \mathrm{C}$ after 6 min of mixing [11]. This results in tissue necrosis and, therefore, it is recommended to cool the prosthesis during implantation. The components of bone cement are sterilized with ethylene oxide or ionizing radiation (powder), as well as by infiltration (liquid). The addition of small amounts of the "radiosubstance" pacifying agent may lower the viscosity [12], and it is of great importance in the surgical process. Cement implanted under pressure is characterized by a very low viscosity, which is favorable for its fixation in the bone, but there is a risk of the monomer penetrating the bloodstream, and also of embolism [11]. Three types of cements are used: low, medium, and high viscosity. Low-viscosity cements have a long mixing phase and a short working phase, and highviscosity cements-just opposite phase periods. In [12] one might find the opinion, that owing to the use of high-viscosity cement, a better fixation of the prosthesis can be obtained, than in the case of low-viscosity cement. With the increase in ambient temperature, the time of cement polymerization decreases, which means that the cement should be implanted in a shorter time.

The PMMA bone cements have some drawbacks as no bioactivity, no antibacterial protection, and excessive brittleness. Therefore, different additions to the base material were proposed as discussed below. Besides, to improve the effectiveness of the treatment for bone defects caused by metastatic bone tumors, the formulation of PMMA cement containing titania and magnetite that offers high bone affinity, making the cement suitable for use in magnetic hyperthermia, was developed [13].

\subsection{Introducing the Bioactivity}

To introduce the bioactivity, the increased cells' proliferation was obtained for PMMA with carbon nanotubes (CNTs) and reduced graphene oxide (rGO) [14]. Other proposals of the same research team were PMMA, monticellite, and CNTs [15], and PMMA together with polycaprolactone (PCL), fluorapatite (FA), and graphene oxide (GO) [16]. The incorporation of multi-walled carbon nanotubes (MWCNTs) into PMMA bone cement improved cytocompatibility and osseointegration [17]. The addition of lactoferrin (LF) on the surface of solidified PMMA bone cement resulted in improving the adhesion, viability, proliferation, and differentiation of preosteoblasts [18]. The cell viability, growth, and cell adhesion increased for PMMA bone cement with 25\% of chitosan/GO composite bone cement [19].

\subsection{Introducing the Antibacterial Properties}

To add an antibacterial barrier, usually, antibiotics were added to impregnate the cements. Such compositions are used routinely in endoprostheses revision. As the effectiveness of antibiotics on the bacterial flora cements produced in the factory is low, the surgeon often prepares cement-antibiotic mixtures during the surgery [12]. The antibioticimpregnated cements remain a gold standard $[20,21]$. Among antibiotics usually applied for bone cements, are vancomycin [22], rifampicin [23], gentamycin [24,25], vancomycin, and gentamycin [26], cefazolin and gentamicin, and amphotericin against various bacteria and Candida biofilms [27], vancomycin, gentamycin and amphotericin [28], vancomycin, daptomycin, and tobramycin [29]. Antibiotic-loaded bone cements are effective by 20 to $84 \%$ to reduce the risk of prosthetic joint infection after implantation surgery [30]. In [31], the titanium dioxide $\left(\mathrm{TiO}_{2}\right)$ nanotubes (TNTs) were formulated with antibiotic-loaded bone cement to enable an enhanced release of antibiotics, more than $50 \%$ of loaded antibiotics (such as gentamicin or vancomycin) were released in two months.

Another group of antibacterial substances is nanometals. Nanomaterials have unique physical-chemical properties, that differ significantly from those of the same materials on a micro and macro scale. These properties include a high surface area to mass ratio, 
high activity, and minimal diffusion restrictions. Nanoparticles significantly contributed to the development of pharmacotherapy, gene therapy, the development of modern drugs and methods of their delivery, and the improvement of imaging diagnostics techniques and other related fields [32]. The addition of nanomaterials can enhance the mechanical properties, fracture toughness if the application type, suitable process, loadings, size, type of nanomaterials are implemented appropriately, but if not, it may negatively influence the mechanical behavior [33]. The most applied is nanosilver [34]. In [35], the PMMA cement loaded with nanosilver at $1 \mathrm{wt}$.\% fully opposed to different bacteria growth, more than gentamycin, at no cytotoxicity. Nanosilver was added as well as antibiotics [36] in bone cements. The positive influence of nanosilver and nanocopper on antibacterial efficiency was reported in [37,38], but also cytotoxicity caused by nanocopper. In [39], silvercontaining bioactive glass powders were prepared by their introduction in the polymer matrix of cement with different viscosity. The silver nanoparticles capped with tiopronin conferred antimicrobial activity against methicillin-resistant Staphylococcus aureus (MRSA) at concentrations as low as $0.1 \mathrm{wt}$.\% [40]. AgNPs at 0.25-1.0 wt.\% introduced into the PMMA cement significantly reduced biofilm [35,41].

The inclusion of AuNPs at $1 \mathrm{wt}$ \% into a PMMA-based bone cement was suggested to reduce the thickness of the biofilm and the ratio of live/dead bacterial cells [42]. Moreover, the carboxylic acid-functionalized polycarbonates were used to enhance the antibacterial performance of the bone cement without deterioration of mechanical strength and cellular biocompatibility [43]. Finally, the MgP nanosheets exhibited antibacterial properties against Escherichia coli [44].

\subsection{Influence of Strengthening Additives on Mechanical Behavior}

The mechanical properties may deteriorate following all admixtures added to bone cement. The reason for this negative impact can be either creating pores or inhibiting polymerization rate. Thorough mixing influences the even distribution of particles in the matrix, which affects the physical properties of the cement. During mixing, considerable amounts of air can be introduced, which results in porosity. These pores, as well as the pores formed by the evaporation of certain amounts of monomer inside the mass [12], may act as stress concentrators, reducing the cement resistance to cracking [10]. According to [12], maintaining the increased pressure during cement implantation ensured better bone penetration through the cement and thus improved the quality of the bone-cement interface, and also increased the fatigue strength of cement.

The compressive strength of bone cement, when it is used to fill the cavities should be at least $30 \mathrm{MPa}$, similar to that of naturally formed spongy bone, and at least $70 \mathrm{MPa}$, if used for fixing endoprostheses, [45]. The main mechanical tests of cement are compressive and bending strength tests-according to ISO and ASTM standards [46,47]. Conventional tests of the functional properties of bone cement mainly verify the polymerization process and basic mechanical properties, under the above standards. They include, apart from testing the cement polymerization process, determination of compressive strength, and bending strength, in a 3- or 4-point bending test, as well as the elastic modulus under bending conditions [48]. An impact test is also performed. Bone cement is characterized by about 2-3 times higher compressive strength, than tensile strength [49]. These properties are of particular importance for the durability of the bone-cement-denture connection in the conditions of the artificial joint operation. Cracks can develop more easily in areas of cement, that are subject to tensile stresses, than in areas of compressive stress. Bone cement is characterized by low impact strength [49,50]. Besides, various types of contaminants or additives as well as inadequate mixing and aging are factors affecting the mechanical properties of cement [51]. Different additives were added to cement to improve the mechanical properties. For example, strength values were observed to have improved by about $20 \%$ with $1.0 \mathrm{~g}$ of Pluronic ${ }^{\circledR}$ F127 (Poloxamer 407; polyol) [52]. 


\subsection{Influence of Antibiotics on Mechanical Behavior}

Concerning the antibiotics, their additions negatively affect the compressive and bending strengths of the cements [24]. For vancomycin-loaded cement [26,53], the strength value was decreased even below the ASTM F451 standard. The addition of gentamicin and amphotericin slightly decreased the compressive strength [27]. The mechanical properties were slightly decreased but if adding antibiotics at high contents [54]. Rifampicin deteriorated the mechanical properties of PMMA causing a delay in the PMMA polymerization [23]. The type of antibiotic was important for mechanical behavior: cefazolin-impregnated cements showed a lower strength than vancomycin-loaded ones [22].

\subsection{Influence of Nanomaterials on Mechanical Behavior}

Different factors are important for the mechanical properties of nanomaterials, as nanoparticle selection, production process, grain size, and grain boundary structure [55]. By introducing nanostructured titania fibers at $1 \mathrm{wt} . \%$ into the cement matrix, with the fibers acting as a reinforcing phase, an increase in resistance to brittle cracking and flexural mechanical strength was substantially improved [56]. The use of hydroxyethyl methacrylate (HEMA) for improving the affinity of TCP/PMMA blends system significantly increased the mechanical properties [57]. The mesoporous silica nanoparticles (MSNs) loaded with antibiotics showed no deterioration of mechanical properties of PMMA bone cement [58].

As regards nanometals, in [37], no negative impact of nanosilver on cement properties was observed, except for bending strength in bone cement with antibiotics. According to [34], the silver nanoparticles demonstrated no influence on the mechanical properties of the dental materials. In [39], for two cements of low and high viscosity, and a high silver content bond in bioglass, good or slightly decreased compression strength concerning the commercial cement was reported. The $0.5 \mathrm{wt} . \%$ of nanosilver significantly increased compressive strength [59]. The silver nanoparticles capped with tiopronin showed no effect on mechanical properties [40]. The inclusion of $0.25 \mathrm{wt} . \%$ of AuNPs also did not negatively alter the compressive properties of the bone cement [42]. The AgNPs at three loading ratios $0.25,0.5$, and $1.0 \mathrm{wt} . \%$ demonstrated mechanical properties that were not substantially different from those of the standard cement [41].

The nano-sized powders of graphene as the reinforcement of PMMA bone cements provided a significant enhancement in mechanical properties, by $12-13 \%$, and when the graphene oxide was applied, the mechanical performance of cements was improved at low amounts of additives; over $0.25 \mathrm{wt} . \%$ resulted in an appearance of the agglomerates and deterioration of mechanical properties [60,61]. Improvement by $40-100 \%$ compressive and tensile strengths was obtained for PMMA with carbon nanotubes (CNTs) and reduced graphene oxide (rGO) [14]. The magnesium phosphate $(\mathrm{MgP})$ nanosheets and hydroxyapatite (HA) nanofibers as novel fillers in PMMA bone cement nanocomposites also improved their compressive strength [44]. Finally, in [19] the addition of chitosan/graphene oxide nanocomposite powder to the PMMA bone cement chitosan at $25 \mathrm{wt} . \%$ increased the compressive strength by $16.2 \%$, the compressive modulus by $69.1 \%$, and the bending strength by $24.0 \%$.

Most recently, the effects of nanoadditives have been considered with different aspects, like dispersion, degradation, corrosion, and nanomechanical properties [62]. The investigations of the effects of $\mathrm{Cu}$-substituted phosphates on mechanical behavior have also not shown any detrimental effects [63].

\subsection{Aim of the Research}

The present work intends to study the behavior of bone cement with and without metallic and potentially antibacterial particles. 


\section{Materials and Methods}

\subsection{Preparation of Samples}

Cemex Isoplastic cement (Tecres S.P.A., Sommacampagna, Italy) was used for the tests. Its mass fractions and chemical composition are shown in Table 1.

Table 1. Composition of Cemex Isoplastic cement.

\begin{tabular}{cc}
\hline Liquid Components (25 wt.\% of Cement) & Powder Components (75 wt.\% of Cement) \\
\hline Methyl methacrylate: $99.10 \mathrm{wt} \%$ & Polymethyl methacrylate: $84.30 \mathrm{wt} . \%$ \\
N-N-dimetylo-p-toluidyne: $0.90 \mathrm{wt} . \%$ & Barium sulfate: $13.00 \mathrm{wt.} \%$ \\
Hydroquinone: 75 ppm wt. $\%$ & Benzoyl peroxide: $2.70 \mathrm{wt} \%$ \\
\hline
\end{tabular}

The tests were carried out with the addition of nanoparticles of selected metal at $1.5 \mathrm{wt} . \%$. The following nanopowders were used: silver (average grain size $40 \mathrm{~nm}$ )—signed as $\mathrm{Ag}$, copper (10-30 nm—signed as $\mathrm{Cu} 10 ; 70-100 \mathrm{~nm}$-signed as $\mathrm{Cu} 70)$, silver with copper $(90 \mathrm{~nm}$ )—signed as $\mathrm{AgCu}$ and nickel (10-30 nm) — signed as Ni. All powders were delivered by MKnano from Mississauga, ON, Canada.

The cement was prepared by mixing cement powder (PMMA), liquid (hardener), and metallic powders. The mixing was performed by hand at room temperature for at least $3 \mathrm{~min}$. Next, the cement was introduced in a metallic mold with 12 holes as presented in Figure 1. The mold was prepared as recommended in the ASTM F451-16 standard [64]. The whole procedure was exactly as recommended by the cement producer. The samples of $6 \mathrm{~mm}$ in diameter and $12 \mathrm{~mm}$ in length were produced with a lapse time between fabrication and testing around $24 \mathrm{~h}$. After, the samples were removed from the mold. Only samples of good shape and conditions of the outside surface were selected for testing. The three samples of each type were tested and the obtained results were averaged.
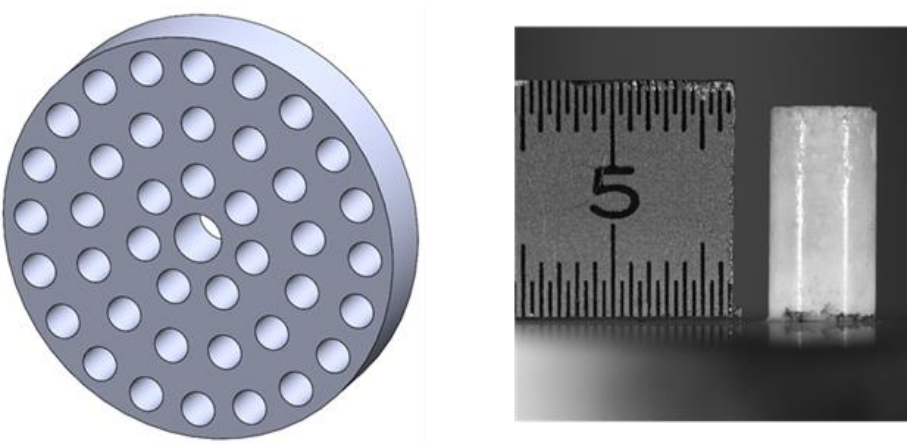

Figure 1. Mold to produce samples and the sample of bone cement prepared using a mold.

\subsection{Bacterial Testing}

Bacterial tests were carried out in a broth solution (Patent No. P 409082 [65]) consisting of a nutrient medium (Table 2) and five strains of bacteria (the relative volumes shown in Table 3) mainly responsible for hospital infections. The bone cement samples were placed in the solution and examined after the 1st day and after 6-month exposure, to reflect the influence of an environment of a living organism. After this period, the samples were taken out of the broth solution to identify the bacteria with a biological microscope (Zeiss Observer D-1, Zeiss, Oberkochen, Germany), and to examine the colonization of bacteria on the surface using a scanning electron microscope (JSM-7800F, JEOL, Tokyo, Japan). 
Table 2. Composition of the bacterial medium [65].

\begin{tabular}{cc}
\hline Ingredient & Content $\left(\mathbf{g} / \mathbf{d m}^{\mathbf{3}}\right)$ \\
\hline Casein peptone & 17 \\
Peptone S & 3 \\
NaCl & 5 \\
$\mathrm{Na}_{2} \mathrm{HPO}_{4}$ & 2.5 \\
Glucose & 2.5 \\
\hline
\end{tabular}

Table 3. Bacterial species used for the test [65].

\begin{tabular}{cc}
\hline Form & Volume Fraction (\%) \\
\hline Staphylococcus aureus & 20 \\
Staphylococcus epidermidis & 20 \\
Enterococcus faecalis & 15 \\
Enterobacter cloacae & 10 \\
Pseudomonas aeruginosa & 35 \\
\hline
\end{tabular}

\subsection{Cell Viability}

A mammalian cell survival test was carried out to evaluate the toxicity of nanopowders added to cements. The cells of Saos- 2 line $\left(\right.$ ATCC ${ }^{\circledR}$ HTB- $85^{\mathrm{TM}}$, LGC Standards, London, UK) were seeded in 96-well plates with McCoy's medium supplemented with $10 \%$ of fetal bovine serum (FBS, Corning Incorporated, Corning, NY, USA) and 1\% of antibiotic penicillin/streptomycin (P/S) (Corning Incorporated, Corning, NY, USA), named as full culture medium. Cells seeded at a concentration of $1 \times 10^{4}$ cells/well were incubated for $24 \mathrm{~h}$ at $37{ }^{\circ} \mathrm{C}$ in $5 \% \mathrm{CO}_{2}$ and $90 \%$ humidity. To determine the toxicity of tested nanoparticles, the protocol proposed by Satyavani et al. was applied [66], namely the prepared solutions of nanometals in full culture medium at contents of 31,62, 125, 250, 500, and $1000 \mu \mathrm{g} / \mathrm{mL}$ for each type were added to wells. The tests made at increasing content reflect the anticipated situation that the nanoparticles are released from the cement in admixture into the surrounding tissue. Cells were further incubated for $24 \mathrm{~h}$ at $37{ }^{\circ} \mathrm{C}$ in $5 \% \mathrm{CO}_{2}$ and $90 \%$ humidity. Cells viability was evaluated by the XTT colorimetric technique. Following a protocol, the XTT reagent (Cell Proliferation Kit XTT, AppliChem GmbH, Darmstadt, Germany) was added to each well for $4 \mathrm{~h}$. Then colorimetric reading was performed using a plate microreader for 450 and $660 \mathrm{~nm}$ wavelengths. The results of the measured absorbance for the individually tested nanoparticles were compared to the results obtained for the control (cells only in contact with the culture medium-signed as negative control (NC)-taken as $100 \%$ viability). Each experiment was repeated three times for each type of nanometal. The relative cell viability (\%) was calculated as a ratio of absorbance of a tested sample containing nanometals to the absorbance of a control sample, expressed in percentage values.

\subsection{Contact Angle Tests}

The measurements were performed with the Attension Theta Lite goniometer (Nanoscience Instruments, Phoenix, AZ, USA) with the use of a drop of distilled water at room temperature, by the falling drop technique. There were 3 samples tested of each type, the surface of each was examined in several places and the means of results and standard deviations were calculated.

\subsection{Compressive Strength Test}

The specimens for testing were prepared and the compression tests were made according to ASTM F451-16 standard with the Shimadzu AGS-X 10KN (Shimadzu Corp., Kyoto, Japan) machine at compression velocity $20 \mathrm{~mm} / \mathrm{min}$. The load and displacement were continuously recorded. The failure loading criterion was defined according to the above standard at $2 \%$ offset upper yield point or the fracture. 


\section{Results}

\subsection{Bacterial Tests}

The bacteria behavior after 1 day and after 6-months exposure to bacteria liquid is shown in Figure 2a,b. After the first day, the solution contains numerous separately spread bacteria, while after 6 months the bacteria are clustered into agglomerates.

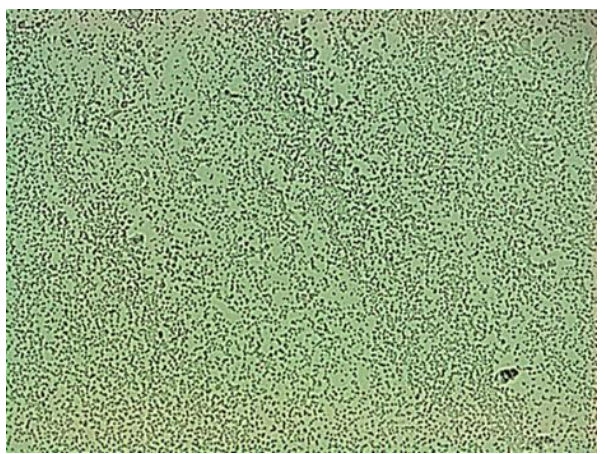

(a)

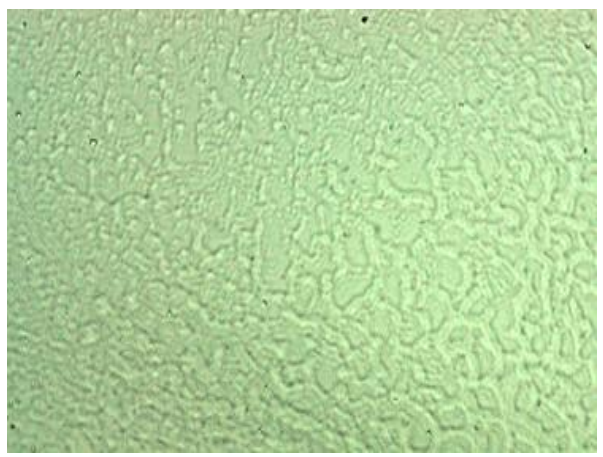

(b)

Figure 2. View of the solution-bacteria liquid: (a) after 1-day; (b) after 6-month. Biological microscope, $630 \times$.

Figure 3a-e illustrates the surfaces of samples of bone cement without and with added different nanometals before placing in the bacterial solution. For $\mathrm{Cu}$, two different powder gradations are shown, 10 and $70 \mathrm{~nm}$.

a
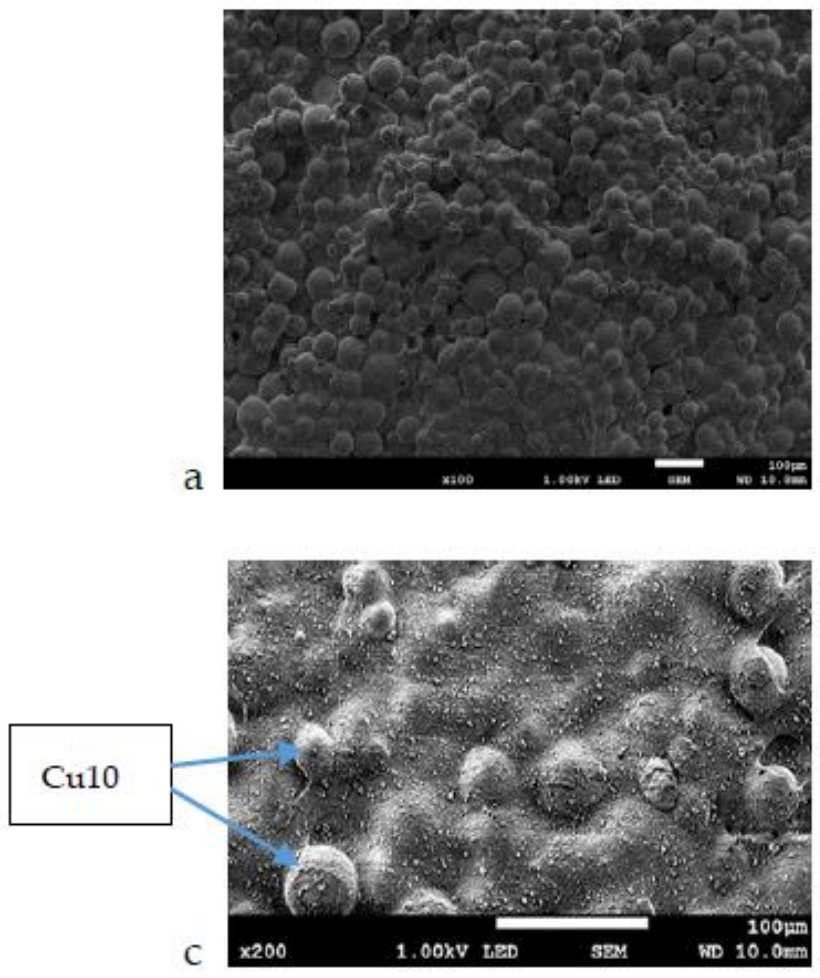

b
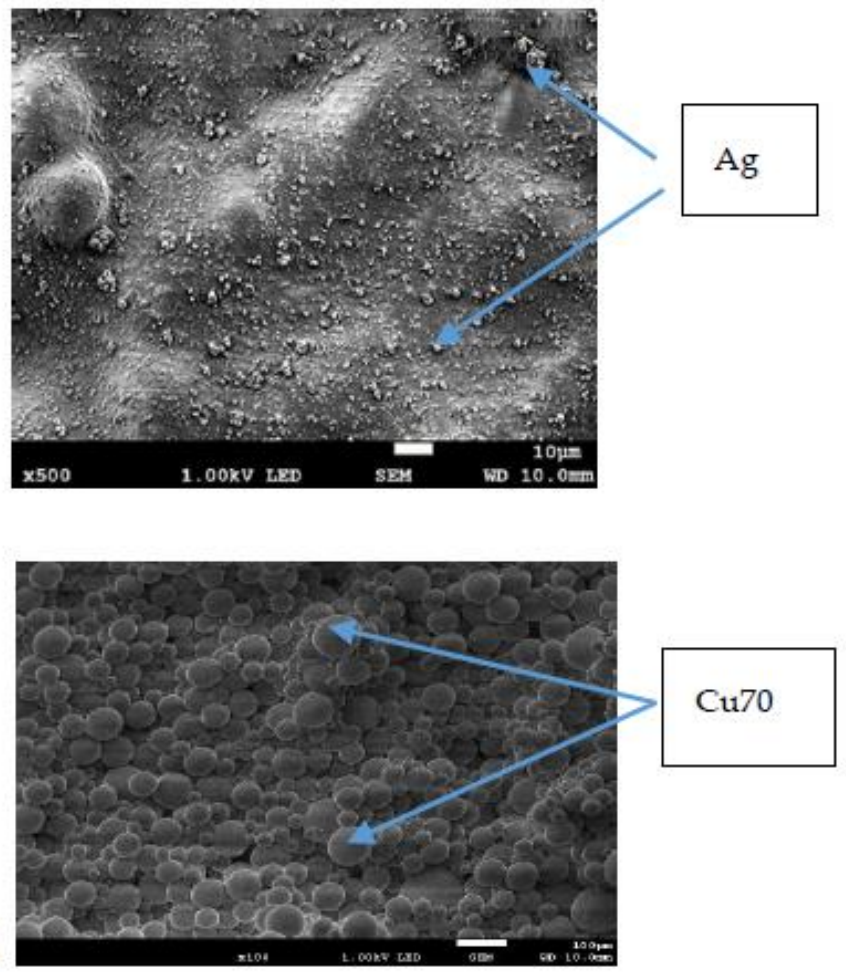

Figure 3. Cont. 

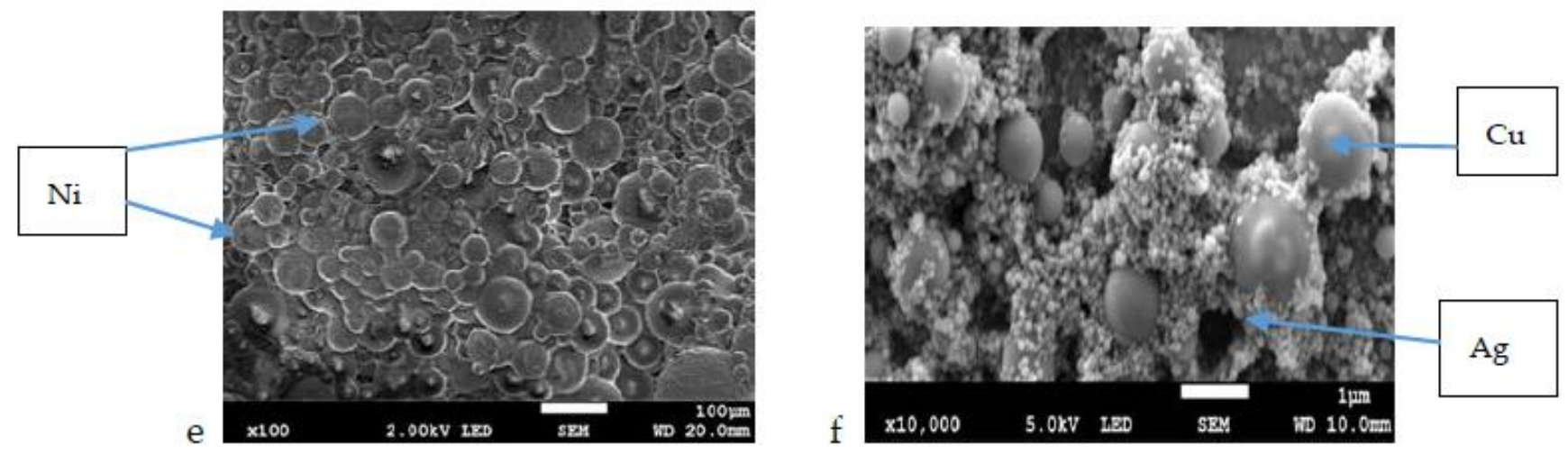

Figure 3. Results of the SEM evaluation of the surfaces of bone cement: (a) pure, and implemented with (b) Ag; (c) Cu 10; (d) Cu 70; (e) Ni; (f) $\mathrm{AgCu}$.

The surfaces of specimens exposed for 1 day to liquid of different bacteria are shown in Figure $4 \mathrm{a}-\mathrm{f}$. After the short-time exposure, the surfaces of all samples were free of bacteria (Figure 4a-f).

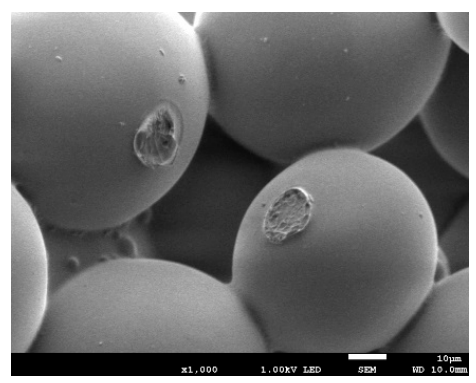

(a)

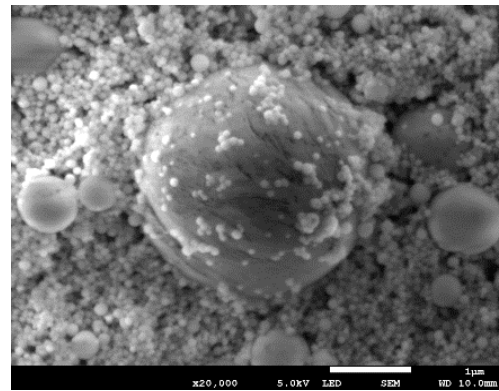

(c)

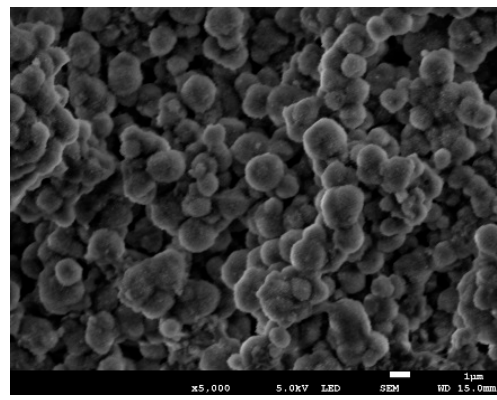

(e)

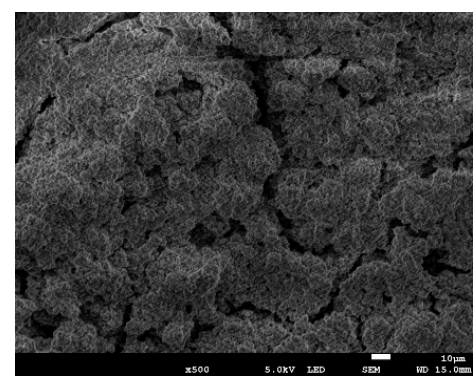

(b)

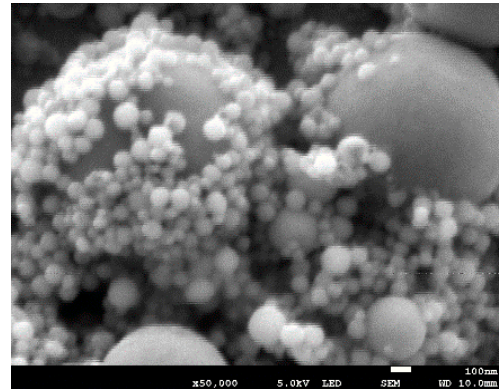

(d)

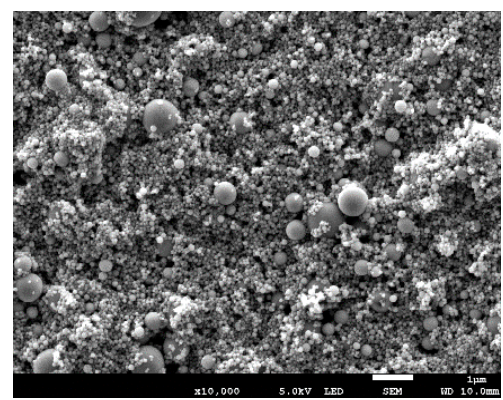

(f)

Figure 4. Results of the SEM evaluation of the surface of bone cement specimen after 1-day exposure in bacteria solution: (a) pure cement; (b) $\mathrm{Ag}$; (c) $\mathrm{Cu} 10 ;$ (d) $\mathrm{Cu} 70 ;($ e) $\mathrm{Ni}$; (f) $\mathrm{AgCu}$. 
Figure 5 shows the surfaces of the samples after 6 months of their exposure. The surface of pure bone cement reveals bacteria and biofilm. Moreover, in the case of $\mathrm{Ni}$ and $\mathrm{AgCu}$ samples, bacteria adhere and biofilm is formed on the surfaces. The surface of the bone cement sample with added Ag has visible pores, without bacteria and biofilm. On both samples $\mathrm{Cu} 10$ and $\mathrm{Cu}$ 70, there are signs of neither bacteria nor biofilm.

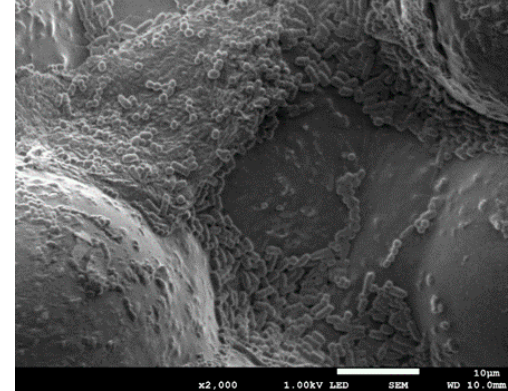

(a)

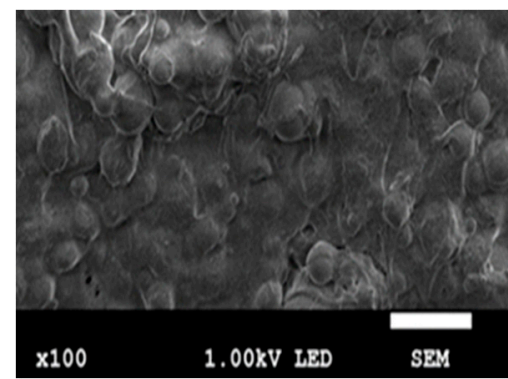

(c)

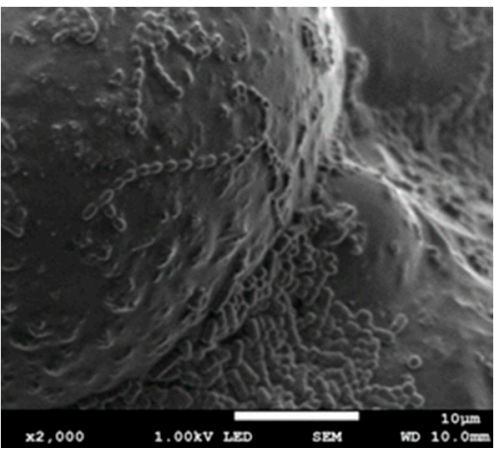

(e)

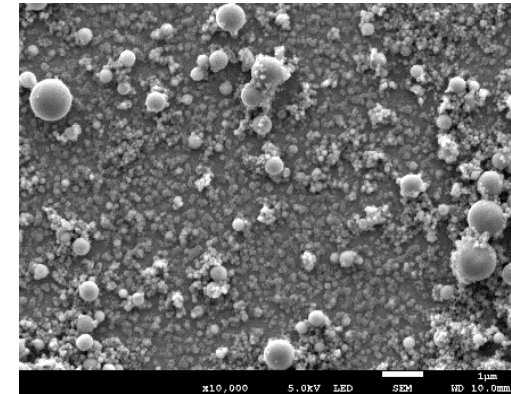

(b)

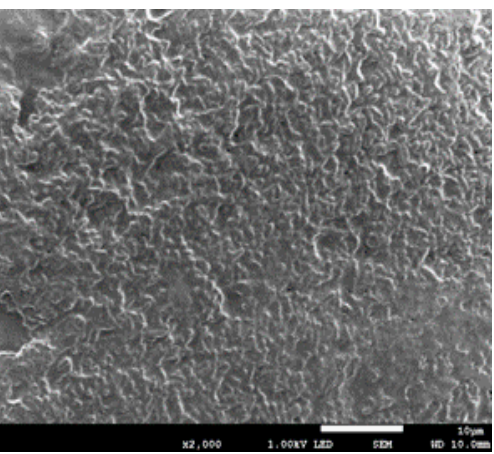

(d)

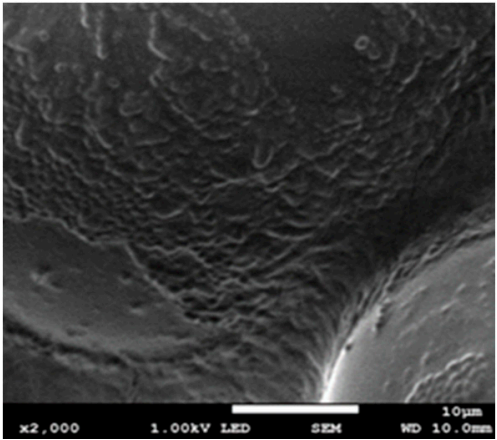

(f)

Figure 5. Results of the SEM evaluation of the bone cement surface after 6 months in the bacteria solution: (a) pure; (b) $\mathrm{Ag}$; (c) $\mathrm{Cu} 10 ;$ (d) $\mathrm{Cu} 70$; (e) Ni; (f) $\mathrm{AgCu}$.

\subsection{Cytotoxicity Tests}

The XTT study (Figure 6) showed that Ni nanoparticles have the most diversified impact on cell viability at $31 \mathrm{mg} / \mathrm{mL}$ content, the viability is at the level of appr. $60 \%$, and at a maximum concentration of $1000 \mathrm{mg} / \mathrm{mL}$, the viability is reduced by half and equals less than $30 \%$. For silver powder, cell survival is low and remains almost at the same level regardless of the concentration-whether $31 \mathrm{mg} / \mathrm{mL}$ or $1000 \mathrm{mg} / \mathrm{mL}$, the survival rate is between 20 and $30 \%$. This may indicate, that more important is the mechanism of action of the silver powder on the cells rather than its quantity. For $\mathrm{AgCu}$ powder it can be seen that only at the lowest concentration $(31 \mathrm{mg} / \mathrm{mL}), \mathrm{Cu}$ has some effect on increasing cell survival (but only by about 10\%). In the remaining concentrations, it does not neutralize 
the effect of $\mathrm{Ag}$ - the survival rate is only slightly higher than that for Ag powders-with increasing concentration of nanoparticles, the viability of cells decreases.

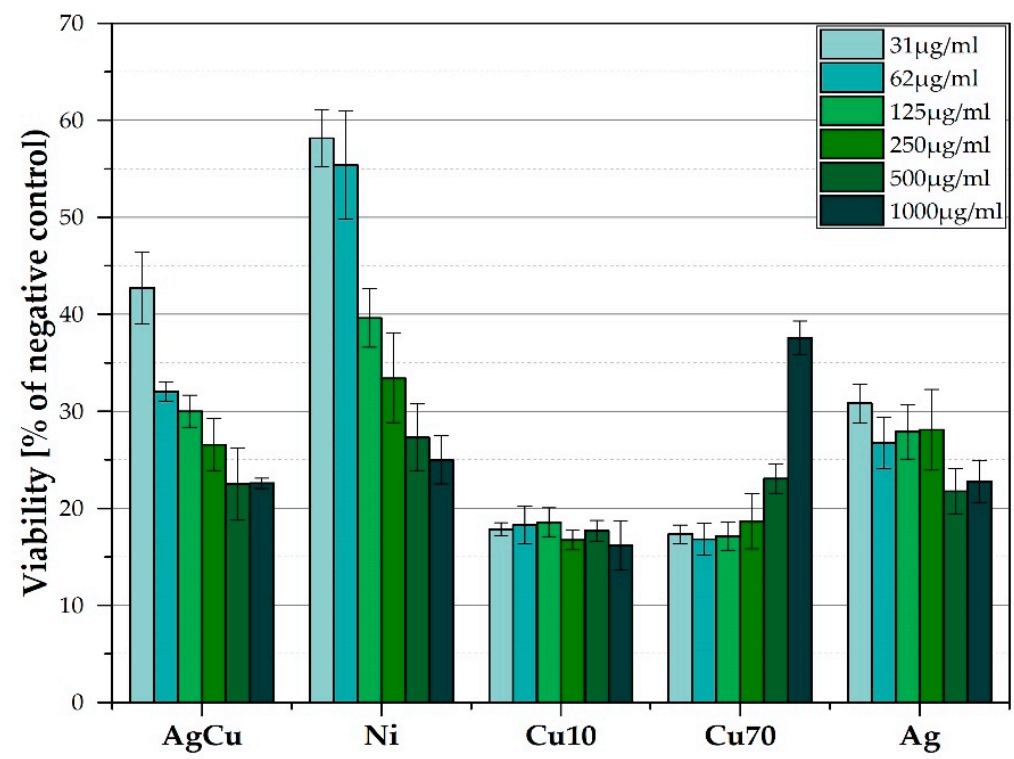

Figure 6. Results of the Saos-2 viability for the examined nanoparticles of silver (Ag), nickel (Ni), silver-copper $(\mathrm{AgCu})$, copper with particles size in a range of 10-30 nm (Cu10), and copper with particles size in a range of 70-100 $\mathrm{nm}(\mathrm{Cu} 70)$.

For Cu70 powders, the results showed the opposite relationship than for other nanoparticles-increasing powder concentration increases cells' survival. The highest concentration of Cu70 powder $(1000 \mathrm{mg} / \mathrm{mL})$ supports cell survival-there are the most and more of them than for lower concentrations. In turn, $\mathrm{Cu} 10$ in the highest concentration causes the greatest reduction in cell survival of all the tested powders, and generally copper nanoparticles in sizes between 10 and $30 \mathrm{~nm}$ cause the lowest cell survival compared to all the tested nanoparticles. This may indicate that the grain size of the powder has an effect on the cells for this material but it is also strictly dependent on the type of material. These two factors determine the influence of nanoparticles on the biological response of the mammalian cells.

\subsection{Wettability Tests}

The contact angle measurements were carried out on samples made of pure bone cement and with nanometals. The test results are presented in Table 4.

Table 4. Water contact angle values for bone cement, pure and with nanometals.

\begin{tabular}{ccccccc}
\hline Sample & Pure Bone Cement & Ag & Cu 10 & Cu 70 & Ni & AgCu \\
\hline Mean value & $106.29 \pm 5.49$ & $127.41 \pm 5.74$ & $139.77 \pm 0.06$ & $138.65 \pm 0.13$ & $125.71 \pm 0.49$ & $107.37 \pm 5.76$ \\
\hline
\end{tabular}

\subsection{Compression Tests}

The samples of bone cement with nanoparticles are presented in Figure 7, a single test for pure cement and each of implemented cements. The relationships are quite similar, demonstrating both linear and plastic regions. 


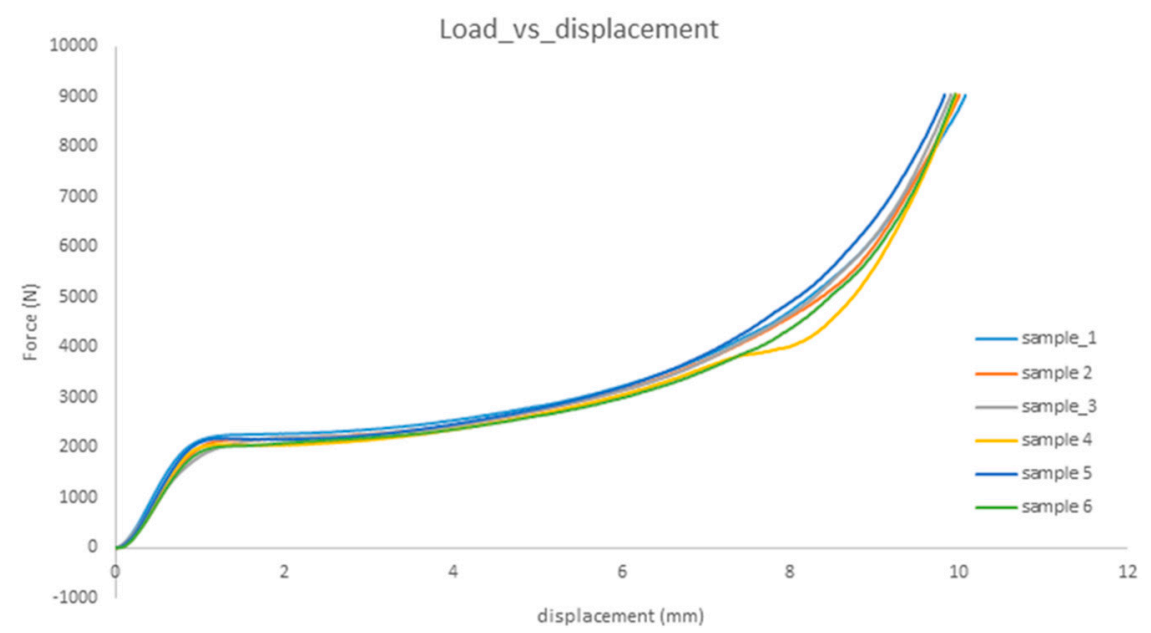

Figure 7. Results of force-displacement for samples of bone cement with nanoparticles; sample 1-pure bone cement; sample 2-Ag; sample 3-Cu10; sample 4-Cu70; sample 5-AgCu; sample 6-Ni.

\section{Discussion}

The present research focused on three different properties of bone cement modified by adding some nanometallic particles. These properties were chosen as essential for the application of bone cement. Antibacterial effectiveness of biomaterial is a significant property as the appearance of bacteria can be dangerous for implant fixation following the possible inflammation states. Wettability is physical property showing the potential of any material to enhance or oppose the adhesion and growth of any cells, including the growth of biofilm caused by bacteria. Finally, any addition of another component to cement may deteriorate or improve its mechanical properties, not often being a subject of testing.

\subsection{Antibacterial Effectiveness and Cytotoxicity}

As known, due to the constant increase in the resistance of bacteria to antibiotics, the nanoparticles may exceed their effectiveness $[67,68]$, because they eliminate the problem of bacterial resistance, and also show bactericidal activity [45]. Nanoparticle carriers seem to be delivered in periods longer compared to antibiotic release [68]. For silver, its antibacterial prevention is well-known [35-41] and proved again by this study. The high efficiency was attained at $\mathrm{Ag}$ contents ranging from 0.1 to $1.0 \mathrm{wt} . \%$, and here the amount of each nanometal was even higher, $1.5 \mathrm{wt} . \%$. On the other side, such high content can be the reason observed here, and previously [69-71] slight cytotoxicity. Therefore, the necessity to maintain the nanosilver amount at a lower level, $0.25-0.5 \mathrm{wt} . \%$, is confirmed. In the case of $\mathrm{Cu}$ nanoparticles, it is here possible to obtain a positive effect on changing the nature of this surface to a hydrophobic one, which works well in combating bacterial adhesion. However, such an effect may also result in a lack of adhesion, and thus low survival of eukaryotic cells. Since the cytotoxicity assessment tests were carried out for pure powders and $1.5 \%$ wt. pct. of each metallic additive was added to the cements, it can be assumed that, while maintaining high bactericidal activity, these materials would not show any toxic effects. It can be seen that with the decreasing concentration of the addition of $\mathrm{Ni}, \mathrm{Ag}$, and $\mathrm{AgCu}$, cell survival increases. In the study of pure $\mathrm{Cu} 10$ and $\mathrm{Cu} 70$ powders, we noticed, however, that they significantly reduced the survival of Saos- 2 cells. This may be related to the grain size of the nanopowder as free powder particles with a diameter of $\leq 32 \mu \mathrm{m}$, at high concentration $\left(10^{6}\right.$ particles $\left./ \mathrm{mL}\right)$, can cause an enhanced immune response of the cells [69]. In the case of larger grain sizes, the cells surround them and try to isolate them from the environment. This neutralizes the action of the nanoparticles but does not kill the cells. For this reason, probably for the Cu70 powder (which has the largest particle size of all tested), the highest cell survival rate is observed for the highest concentration. On the other side, the possible cytotoxicity of copper nanoparticles was reported several 
times [68,72-75], even if it depends on the amount and size of particles. In the case of samples of cement without additives, and cement with nanoparticles of $\mathrm{Ni}$ and $\mathrm{AgCu}$, adhering bacteria were observed on their surface after 6 months. In the case of $\mathrm{AgCu}$ addition, their grains are relatively large, they do not tightly fill the pores of pure cement (Figure 5f), thus creating good conditions for bacteria. So far, no studies on $\mathrm{AgCu}$ were revealed in the literature to compare. The $\mathrm{Ni}$ additive grains, although they are quite small to reduce the surface roughness, they nonetheless exhibit no antibacterial effect. In the case of this additive, studies of the powders themselves in contact with mammalian cells demonstrated that all metallic nanoparticles had a certain effect on the vitality of cells, and the addition of $\mathrm{Ni}$ reduced the vitality of Saos- 2 cells to the smallest extent [76,77]. All these phenomena may be related to both the toxic effect of metal ions (regardless of whether they attack the cell membrane or make adhesion of bacteria easier or do not prevent it), apparently higher for copper than for silver and size of the nanoparticle, more dangerous at smaller dimensions [72,75].

\subsection{Wettability}

Research conducted by Marciano et al. [78] indicated that with the increase of the hydrophobicity of the surface, its antibacterial activity increases. This relation was also confirmed here by the tests of the contact angle and bacterial colonization. For samples $\mathrm{Cu} 10$ and $\mathrm{Cu} 70$, the contact angle was the highest, which proves their hydrophobicity. On these samples, even after 6 months of exposure to five species of bacteria, their presence was not observed. It might be then said that hydrophobic surfaces even if do not help osteoblasts to adhere, counteract the formation of biofilm. For what cells, osteoblasts or bacteria cells, this moderate hydrophobicity is more preferred, it is difficult to say without further thorough studies in the simultaneous presence of both forms of cells. The samples with $\mathrm{Ag}$ admixture were also free from bacteria. This is probably the effect of silver, which is well-known for its strong (the strongest among all nanomaterials) antibacterial properties. Moreover, according to some previous studies $[79,80]$, the number of bacteria decreases when surface roughness decreases. Ag nanoparticles with a size of $40 \mathrm{~nm}$ fill the pores of the pure cement matrix, which reduces the surface roughness parameters and thus enhances its antibacterial properties.

\subsection{Mechanical Behavior}

Bone cement is expected to maintain its properties for a long time. An important, unfavorable feature of cement is its tendency to degrade, consisting of the loss of its original properties over time under the influence of the organism's environment $[49,81,82]$. It is influenced by the aging processes of this material, additionally accelerated by the influence of the organism's environment [83]. The phenomena typical for viscoelastic materials, including polymers, are creep and relaxation [84]. The most important factors related to the organism's environment, that have an adverse effect on the mechanical characteristics such as static and fatigue strength fracture and creep resistance, include: cement contamination with blood and bone remains, factors related to the surgical technique, such as improper mixing and kneading techniques, delayed introduction of cement to the bone, an admixture of antibiotics and addition of a contrast agent, increased body temperature, the influence of physiological fluids (moisture and aging processes). A long time of its stay in the organism's environment has a significant influence on the mechanical characteristics of cement $[49,83,85]$. During the use of artificial joints, especially hip joints, in which endoprostheses are fixed with bone cement, cement is subject to a cyclical loading process, which leads to fatigue cracking and, consequently, loosening of the endoprostheses [86-90]. Additionally, the greatest torsional loads affect the prosthesis $[87,91,92]$. The phenomenon of the destruction of the biomechanical connection of the prosthesis stem with the femur during human movement takes place under the action of cyclical load changes of high values and low frequencies, so it can be described with high probability as fatigue in the range of a small number of cycles [83]. 
Therefore, the chemical and phase composition of cements are important as they may affect mechanical properties. The results in these experiments of bone cement, with and without nanoparticles, are similar between samples, with a linear part and a plastic region and after with a densification region. The observed results are in accordance with a lot of earlier research for different nanomaterials. Mechanical behavior of PMMA biopolymer was improved with some nanoadditives [90,93]. In [91], the improving various injectable materials can be obtained by using nanomaterials ( $\mathrm{Ag}, \mathrm{Cu}, \mathrm{Ni}, \mathrm{AgCu}$ [ [94]. According to [16], adding fluorapatite (FA) and graphene oxide (GO) to PMMA-PCL polymer increases the mechanical properties of cement; in particular, FA increased the compressive strength and elastic modulus while reducing elongation. The modification of PMMA by carbon nanotubes increased Young's modulus by $19 \%$ and hardness by $36 \%$ at a content of $0.15 \mathrm{wt} . \%$ [95]. The $\mathrm{SiO}_{2}$ nanoparticles improved the compression properties of PU foam, in particular at $0.5 \mathrm{wt} \% \mathrm{SiO}_{2}$ elevating by 180 and $40 \%$ the compressive plateau and densification stress.

However, the nanoHA particles present in porous PU enhanced the compression resistance by $37 \%$, but shorten the compression recovery time by $41 \%$, and reduced the tensile resistance by $78 \%$. In compression tests, the PMMA cement with calcium silicate retained acceptable mechanical strength and injectability [96]. On the other side, the addition of hydroxyapatite caused a decrease in the fracture toughness of nanocomposite under any stress mode [90]. The possible worsening of properties is related to element and grain size; nanocrystalline $\mathrm{Cu}$ had yield stresses of $450-600 \mathrm{MPa}$ and strains to failure of $2-3 \%$, but the only elastic region in nanocrystalline $\mathrm{Ni}$ with fractures stresses of $1200-1500 \mathrm{MPa}$, which was attributed to the grain size effect. Generally, the nanosilver caused no [34,37,40,42], or only limited $[39,41]$ changes in mechanical properties, or even increased compression strength [59]. The present results are evidence that also other metallic nanomaterials which do not interact with cement components, have similar characteristics which scarcely depend (see results for nanocopper) on particle size in this range.

\section{Conclusions}

The antibacterial effect significantly depends on the metallic element. It is the most prominent for nanosilver and nanocopper, and negligible for $\mathrm{AgCu}$ and nickel nanoparticles. Most likely, the observed effects are dependent on the interaction strength and killing mechanism of metal atoms or ions with bacteria cells. The antibacterial effect is the strongest at the very beginning, after 1st day of exposure, and vanishes after 6 months of exposure for all elements except nanosilver.

The cytotoxicity appears and is similar for all investigated elements, nanosilver including. The effect may be attributed to the relatively high concentration of elements and, for nickel and copper, exceptionally strong effectiveness of killing cells, including both body cells and bacteria.

The presence of all nanometals causes the appearance of hydrophobic surfaces, more than for pure cement.

The mechanical properties are not negatively influenced by any of the elements in nanoform.

Author Contributions: Conceptualization, B.Ś.-Ż.; formal analysis, B.Ś.-Ż., A.Z.; investigation, B.Ś.ZŻ.; resources, B.Ś.Ż̇., D.B.; data curation, B.Ś.-Ż., D.B.; writing-original draft preparation, B.S.'-Ż., A.Z., D.B., G.G., K.R.; writing-review and editing B.Ś.-Ż, A.Z., D.B.; visualization, B.Ś.Ż̇., A.Z.; supervision, B.Ś.Ż̇., A.Z., D.B.; project administration, B.Ś.Ż̇., A.Z.; funding acquisition, B.Ś.-Ż. All authors have read and agreed to the published version of the manuscript.

Funding: The research was financed by the Gdańsk University of Technology.

Data Availability Statement: The data presented in this study are available on request from the corresponding author.

Acknowledgments: The technical contribution into mechanical tests of Antonio Ramos, University of Aveiro, Department of Mechanical Engineering, is gratefully acknowledged. 
Conflicts of Interest: The authors declare no conflict of interest.

\section{References}

1. Motameni, A.; Alshemary, A.Z.; Evis, Z. A review of synthesis methods, properties and use of monetite cements as filler for bone defects. Ceram. Int. 2021, 47, 13245-13256. [CrossRef]

2. Ginebra, M.-P.; Montufar, E.B. Cements as bone repair materials. In Woodhead Publishing Series in Biomaterials, Bone Repair Biomaterials, 2nd ed.; Kendell, M., Pawelec, J., Planell, A., Eds.; Woodhead Publishing: Sawston, UK, 2019; pp. 233-271. [CrossRef]

3. Rey-Vinolas, S.; Engel, E.; Mateos-Timoneda, M.A. Polymers for bone repair. In Woodhead Publishing Series in Biomaterials, Bone Repair Biomaterials, 2nd ed.; Kendell, M., Pawelec, J., Planell, A., Eds.; Woodhead Publishing: Sawston, UK, 2019 ; pp. $179-197$. [CrossRef]

4. $\quad$ Sayeed, Z.; Padela, M.T.; El-Othmani, M.M.; Saleh, K.J. Woodhead Publishing Series in Biomaterials, Bone Repair Biomaterials, 2nd ed.; Ambrosio, L., Ed.; Woodhead Publishing: Sawston, UK, 2017; pp. 199-214. [CrossRef]

5. Raju, V.; Mayank, C.; Abhishek, V. Bone cement-Review article. J. Clin. Orthop. Trauma 2013, 4, 157-164. [CrossRef]

6. Cools, P.; De Geyter, N.; Vanderleyden, E.; Barberis, F.; Dubruel, P.; Morent, R. Adhesion improvement at the PMMA bone cement-titanium implant interface using methyl methacrylate atmospheric pressure plasma polymerization. Surf. Coat. Techn. 2016, 294, 201-209. [CrossRef]

7. Cecen, B.; Kalemtas, A.; Topates, G.; Kozaci, L.D. Cellular response to calcium phosphate cements. In Woodhead Publishing Series in Biomaterials, Bone Repair Biomaterials, 2nd ed.; Mozafari, M., Ed.; Woodhead Publishing: Sawston, UK, 2019 ; pp. 369-393. [CrossRef]

8. Kucko, N.W.; Herber, R.-P.; Leeuwenburgh, S.; Jansen, J.A. Calcium Phosphate Bioceramics and Cements. In Principles of Regenerative Medicine, 3rd ed.; Atala, A., Lanza, R., Mikos, A.G., Nerem, R., Eds.; Academic Press: Cambridge, MA, USA, 2019; pp. 591-611. [CrossRef]

9. Hurle, K.; Oliveira, J.M.; Reis, R.L.; Pina, S.; Goetz-Neunhoeffer, F. Ion-doped brushite cements for bone regeneration. Acta Biomater. 2021, 123, 51-71. [CrossRef]

10. Bishop, N.E.; Ferguson, S.; Tepic, S. Porosity reduction in bone cement at the cement-Stem interface. J. Bone Jt. Surg. 1996, 78, 349-356. [CrossRef]

11. Donaldson, A.J.; Thomson, H.E.; Harper, J.; Kenny, N.W. Bone cement implantation syndrome. Oxf. J. Medic. Health BJA 2009, 102, 12-22. [CrossRef]

12. Zimmer, K.; Pradellok, W. Bone cements. In Biomaterials (Vol. 4). Problems of Biocybernetics and Biomedical Engineering; Nałęcz, W., Ed.; Publ. House of Commun.: Warszawa, Poland, 1990; pp. 251-263.

13. Kubota, M.; Yokoi, T.; Ogawa, T.; Saito, S.; Furuya, M.; Yokota, K.; Kanetaka, H.; Jeyadevan, B.; Kawashita, M. In-vitro heatgenerating and apatite-forming abilities of PMMA bone cement containing $\mathrm{TiO}_{2}$ and $\mathrm{Fe}_{3} \mathrm{O}_{4}$. Ceram. Int. 2021, 47, 12292-12299. [CrossRef]

14. Pahlevanzadeh, F.; Bakhsheshi-Rad, H.R.; Kharaziha, M.; Kasiri-Asgarani, M.; Omidi, M.; Razzaghi, M.; Ismail, A.F.; Sharif, S.; Rama Krishna, S.; Berto, F. CNT and rGo reinforced PMMA based bone cement for fixation of load bearing implants: Mechanical property and biological response. J. Mech. Behav. Biomed. Mater. 2021, 116, 104320. [CrossRef]

15. Pahlevanzadeh, F.; Bakhsheshi-Rad, H.R.; Ismail, A.F.; Aziz, M.; Chen, X.B. Development of PMMA-Mon-CNT bone cement with superior mechanical properties and favorable biological properties for use in bone-defect treatment. Mater. Lett. 2019, $240,9-12$. [CrossRef]

16. Pahlevanzadeh, F.; Bakhsheshi-Rad, H.R.; Hamzah, E. In-vitro biocompatibility, bioactivity, and mechanical strength of PMMAPCL polymer containing fluorapatite and grapheme oxide bone cements. J. Mech. Behav. Biomed. Mater. 2018, 82, 257-267. [CrossRef]

17. Wang, C.; Yu, B.; Fan, Y.; Ormsby, R.W.; McCarthy, H.O.; Dunne, N.; Li, X. Incorporation of multi-walled carbon nanotubes to PMMA bone cement improves cytocompatibility and osseointegration. Mater. Sci. Eng. C 2019, 103, 109823. [CrossRef]

18. Xu, D.; Song, W.; Zhang, J.; Liu, Y.; Lu, Y.; Zhang, X.; Liu, Q.; Yuan, T.; Liu, R. Osteogenic effect of polymethyl methacrylate bone cement with surface modification of lactoferrin. J. Biosci. Bioeng. 2021, 132, 132-139. [CrossRef]

19. Tavakoli, M.; Eil Bakhtiari, S.S.; Karbasi, S. Incorporation of chitosan/grapheme oxide nanocomposite into the PMMA bone cement: Physical, mechanical and biological evaluation. Int. J. Bio. Macromol. 2020, 149, 783-793. [CrossRef] [PubMed]

20. Wentao, Z.; Lei, G.; Liu, Y.; Wang, W.; Song, T.; Fan, J. Approach to osteomyelitis treatment with antibiotic loaded PMMA. Microbal. Pathog. 2017, 102, 42-44. [CrossRef] [PubMed]

21. Kojima, K.E.; de Andrade e Silva, F.B.; de Camargo Leonhardt, M.; de Carvalho, V.C.; de Oliveira, P.R.D.; Lima, A.L.L.M.; dos Reis, P.R.; dos Santos Silva, J. Bioactive glass S53P4 to fill-up large cavitary bone defect after acute and chronic osteomyelitis treated with antibiotic-loaded cement beads: A prospective case series with a minimum 2-year follow-up. Injury 2021, 52, S23-S28. [CrossRef] [PubMed]

22. Paz, E.; Sanz-Ruiz, P.; Abenojar, J.; Vaquero-Martin, J.; Forriol, F.; del Real, J.C. Evaluation of elution and mechanical properties ofhigh-dose antibiotic-loaded bone cement: Comparative in vitro study of the influence of vancomycin and cefazolin. J. Arthoplasty 2021, in press. [CrossRef] 
23. Carbo-Laso, E.; Sanz-Ruiz, P.; del Real-Romero, J.C.; Ballesteros-Iglesias, Y.; Paz-Jimenez, E.; Aran-Ais, F.; Sanchez-Navarro, M.; Perez-Liminana, M.A.; Lopez-Torres, I.; Vaquero-Martin, J. New method for antibiotic release from bone cement (polymethylmethacrylate): Redefining boundaries. Rev. Esp. Cir. Ortopd. Traumatol. 2018, 62, 86-92. [CrossRef]

24. Dunne, N.J.; Hill, J.; McAfee, P.; Kirkpatrick, R.; Patrick, S.; Tunney, M. Incorporation of large amounts of gentamicin sulphate into acrylic bone cement: Effect on handling and mechanical properties, antibiotic release and biofilm formation. Proc. Inst. Mech. Eng. Part H J. Eng. Med. 2008, 222, 355-365. [CrossRef]

25. Karaglani, M.; Tzitzikou, E.; Tottas, S.; Kougioumtzis, I.; Arvanitidis, K.; Kolios, G.; Chatzaki, E.; Drosos, G.I. Gentamycin elution from polymethylmethacrylate and bone graft substitute: Comparison between commercially available and home-made preparations. J. Orthop. 2020, 19, 9-13. [CrossRef]

26. Mensah, L.M.; Love, B.J. A meta-analysis of bone cement mediated antibiotic release: Overkill, but a viable approach to eradicate osteomyelitis and other infections tied to open procedures. Mater. Sci. Eng. C 2021, 123, 111999. [CrossRef]

27. Czuban, M.; Wulsten, D.; Wang, L.; Di Luca, M.; Trampuz, E. Release of different amphotericin B formulations from PMMA bone cements and their activity against Candida biofilm. Colloids Surf. B Biointerfaces 2019, 183, 110406. [CrossRef] [PubMed]

28. Heidenreich, M.J.; Tetreault, M.W.; Lewallen, D.G.; Perry, K.I.; Hanssen, A.D.; Abdel, M.P. Total femur antibiotic spacers: Effective salvage for complex periprosthetic joint infections. J. Arthoplast. 2021, 36, 2567-2574. [CrossRef] [PubMed]

29. Meeker, D.G.; Cooper, K.B.; Renard, R.L.; Mears, S.C.; Smelzer, M.S.; Barnes, C.L. Comparative study of antibiotic elution profiles from alternative formulations of polymethylmethacrylate bone cement. J. Arthroplast. 2019, 34, 1458-1461. [CrossRef] [PubMed]

30. Sebastian, S.; Liu, Y.; Christensen, R.; Raina, D.B.; Tagil, M.; Lidgren, L. Antibiotic containing bone cement in prevention of hip and knee prosthetic joint infections: A systematic review and meta-analysis. J. Orthop. Transl. 2020, 23, 53-60. [CrossRef]

31. Shen, S.-C.; Letchmanan, K.; Chow, P.S.; Tan, R.B.H. Antibiotic elution and mechanical property of $\mathrm{TiO}_{2}$ nanotubes functionalized PMMA-based bone cements. J. Mech. Behav. Biomed. Mater. 2019, 91, 91-98. [CrossRef]

32. Chou, C.; Chang, J.-L.; Zen, J.-M. Spherical and Anisotropic Copper Nanomaterials in Medical Diagnosis. In Metallic Nanomaterials; Kumar, C.S.S.R., Ed.; Wiley-VCH: Weinheim, Germany, 2009.

33. Woldemariam, M.H.; Belingardi, G.; Koricho, E.G.; Reda, D.T. Effects of nanomaterials and particles on mechanical properties and fracture toughness of composite materials: A short review. AIMS Mater. Sci. 2019, 6, 1191-1212. [CrossRef]

34. Bapat, R.A.; Chaubal, T.V.; Joshi, C.P.; Bapat, P.R.; Choudhury, H.; Pandey, M.; Gorain, B.; Kesharwani, P. An overview of application of silver nanoparticles for biomaterials in dentistry. Mater. Sci. Eng. C 2018, 91, 881-898. [CrossRef]

35. Alt, V.; Bechert, T.; Steinrucke, P.; Wagener, M.; Seidel, P.; Dingeldein, E.; Domann, E.; Schnettler, R. An in vivo assessment of the antibacterial properties and cytotoxicity of nanoparticulate silver bone cement. Biomaterials 2004, 25, 4383-4391. [CrossRef]

36. Chaloupka, K.; Malam, Y.; Seifalian, A.M. Nanosilver as a new generation of nanoproduct in biomedical applications. Trends Biotechnol. 2010, 28, 580-588. [CrossRef]

37. Wekwejt, M.; Moritz, M.; Świeczko-Żurek, B.; Pałubicka, A. Biomechanical testing of bioactive bone cement-a comparison of the impact of modifiers: Antibiotics and nanometals. Polym. Test. 2018, 70, 234-243. [CrossRef]

38. Wekwejt, M.; Michalska-Sionkowska, M.; Bartmański, M.; Nadolska, M.; Łukowicz, K.; Pałubicka, A.; Osyczka, A.M.; Zieliński, A Influence of several biodegradable components addend to pure and nanosilver-doped PMMA bone cements on its biological and mechanical properties. Mat. Sci. Eng. C 2020, 117, 111286. [CrossRef] [PubMed]

39. Miola, M.; Bruno, M.; Maina, G.; Fucale, G.; Lucchetta, G.; Verne, E. Antibiotic-free composite bone cements with antibacterial and bioactive properties. A preliminary study. Mater. Sci. Eng. C 2014, 43, 65-75. [CrossRef] [PubMed]

40. Prokopovich, P.; Leech, R.; Parkin, I.P.; Perni, S. A novel bone cement impregnated with silver-tiopronim nanoparticles: Its antimicrobial, cytotoxic and mechanical properties. Int. J. Nanomed. 2013, 8, 2227-2237. [CrossRef] [PubMed]

41. Slane, J.; Vivanco, J.; Rose, W.; Ploeg, H.-L.; Squire, M. Mechanical, material and antimicrobial properties of acrylic bone cement impregnated with silver nanoparticles. Mater. Sci. Eng. C 2015, 48, 188-196. [CrossRef] [PubMed]

42. Russo, T.; Gloria, A.; De Santis, R.; D’Amora, U.; Balato, G.; Vollaro, A.; Oliviero, O.; Improta, G.; Triassi, M.; Ambrosio, L. Preliminary focus on the mechanical and antibacterial activity of a PMMA-based bone cement loaded with gold nanoparticles. Bioact. Mater. 2017, 2, 156-161. [CrossRef]

43. Liang, Z.C.; Yang, C.; Ding, X.; Hedrick, J.L.; Wang, W.; Yang, Y.Y. Carboxylic acid-functionalized polycarbonates as bone cement additives for enhanced and sustained release of antibiotics. J. Control. Release 2021, 329, 871-881. [CrossRef]

44. Phakatkar, A.H.; Shirdar, M.R.; Qi, M.; Taheri, M.M.; Narayanan, S.; Foroozan, T.; Sharifi-Asl, S.; Huang, Z.; Agrawal, M.; Lu, Y.; et al. Novel PMMA bone cement nanocomposite containing magnesium phosphate nanosheets and hydroxyapatite nanofibers. Mater. Sci. Eng. C 2020, 109, 110497. [CrossRef]

45. Wekwejt, M.; Świeczko-Żurek, B. Bioactivity and biofunctionality of bone cement. In Trends and Technological Solutions: Responses to the Needs of Modern Society; Gdańsk University of Technology: Gdańsk, Poland, 2017; Volume 1, pp. $202-211$.

46. Standard ASTM F 451-08; Standard Specification for Acrylic Bone Cement. ASTM International: West Conshohocken, PA, USA, September 2008.

47. Standard ISO 5833:2002; Implants for Surgery-Acrylic Resin Cements. ISO 2002: Geneva, Switzerland, 2002.

48. Kuhn, K.D. Bone Cements; Springer: Berlin/Heidelberg, Germany, 2000.

49. Driessens, F.C.M.; Planell, J.A.; Boltong, M.G.; Khairoun, I.; Ginebra, M.P. Osteotransductive bone cements. J. Eng. Med. 1998, 212, 427-435. [CrossRef] 
50. Nowacki, J.; Dobrzański, L.A.; Gustavo, F. Intramedullary implants in the osteosynthesis of long bones. Bonding biomaterials and implant components. Sci. Int. J. World Acad. Mater. Manufact. Eng. 2012, 111, 114-129.

51. Tuncer, K.; Gur, B.; Senol, O.; Aydin, M.R.; Gungogdu, O. New bone cements with Pluronic F127 for prophylaxis and treatment of periprosthetic joint infections. J. Mech. Behav. Biomed. Mater. 2012, 119, 104496. [CrossRef]

52. Baleani, M.; Persson, C.; Zolezzi, C.; Andollina, A.; Borrelli, A.M.; Tigani, D. Biological and biomechanical effects of vancomycin and meropenem in acrylic bone cement. J. Arthroplast. 2008, 23, 1232-1238. [CrossRef]

53. Cacciola, G.; De Meo, F.; Cavaliere, P. Mechanical and elution properties of G3 low viscosity bone cement loaded up to three antibiotics. J. Orthop. 2018, 15, 1004-1007. [CrossRef]

54. Wu, Q.; Miao, W.-S.; Zhang, Y.-D.; Gao, H.-J.; Hui, D. Mechanical properties of nanomaterials: A review. Nanotechn. Rev. 2020, 9, 259-273. [CrossRef]

55. Khaled, S.M.Z.; Charpentier, P.A.; Rizkalla, A.S. Physical and mechanical properties of PMMA bone cement reinforced with nano-sized titania fibers. J. Biomater. Appl. 2011, 25, 515-537. [CrossRef]

56. Gao, S.; Lv, Y.; Yuan, L.; Ren, H.; Wu, T.; Liu, B.; Zhang, Y.; Zhou, R.; Li, A.; Zhou, F. Improved bone ingrowth of tricalcium phosphate filled Poly (methyl metacrylate) (PMMA) bone cements in vivo. Polym. Test. 2019, 76, 513-521. [CrossRef]

57. Letchmanan, K.; Shen, S.-C.; Ng, W.K.; Kingshuk, P.; Shi, Z.; Wang, W.; Tan, R. Mechanical properties and antibiotic release characteristic of poly (methyl methacrylate)-based bone cement formulated with mesoporous silica nanoparticles. J. Mech. Behav. Biomed. Mat. 2017, 72, 163-170. [CrossRef]

58. Paiva, L.; Fidalgo, T.K.S.; da Costa, L.P.; Maia, L.C.; Balan, L.; Anselme, K.; Ploux, I. Antibacterial properties and compressive strength of new one-step preparation silver nanoparticles in glass ionomer cements (NanoAg-GIC). J. Dent. 2018, 69, 102-109. [CrossRef]

59. Paz, E.; Forriol, F.; del Real, J.C.; Dunne, N.J. Graphene oxide versus graphene for optimization of PMMA bone cement for orthopaedic applications. Mater. Sci. Eng. C 2017, 77, 1003-1011. [CrossRef]

60. Paz, E.; Ballesteros, Y.; Forriol, F.; Dunne, N.J.; del Real, J.C. Graphene and graphene oxide functionalisation with silanes for advanced dispersion and reinforcement of PMMA-based bone cements. Mater. Sci. Eng. C 2019, 104, 109946. [CrossRef]

61. Du, S.; Wu, J.; Al Shareedah, O.; Shi, X. Nanotechnology in Cement-Based Materials: A Review of Durability, Modeling, and Advanced Characterization. Nanomaterials 2019, 9, 1213. [CrossRef]

62. De Santis, R.; Russo, T.; Rau, J.V.; Papallo, I.; Martorelli, M.; Gloria, A. Design of 3D Additively Manufactured Hybrid Structures for Cranioplasty. Materials 2021, 14, 181. [CrossRef]

63. Russo, T.; De Santis, R.; Gloria, A.; Barbaro, K.; Altigeri, A.; Fadeeva, I.V.; Rau, J.V. Modification of PMMA Cements for Cranioplasty with Bioactive Glass and Copper Doped Tricalcium Phosphate Particles. Polymers 2020, 12, 37. [CrossRef]

64. ASTM F451-16; Standard Specification for Acrylic Bone Cement. ASTM International: West Conshohocken, PA, USA, October 2016.

65. Świeczko-Żurek, B. Method of Assessing Biodegradation of Metallic Implants, a Method of Obtaining a Bacterial Solution for Assessing Biodegradation of Metallic Implants and a Bacterial Composition for Assessing Biodegradation of Metallic Implants. Poland Patent Application No. 409082, 4 August 2015.

66. Satyavani, K.; Gurudeeban, S.; Ramanathan, T.; Balasubramanian, T. Toxicity Study of Silver Nanoparticles Synthesized from Suaeda monoica on Hep-2 Cell Line. Avicenna J. Med. Biotechnol. 2012, 4, 35-39.

67. Fahmy, H.M.; Ebrahim, N.M.; Gaber, M.H. In-vitro evaluation of copper/copper oxide nanoparticles cytotoxicity and genotoxicity in normal and cancer lung cell lines. J. Trace Elem. Med. Biol. 2020,60, 126481. [CrossRef]

68. Greulich, C.; Diendorf, J.; Gessmann, J.; Simon, T.; Habijan, T.; Eggeler, G.; Schildhauer, T.A.; Epple, M.; Koller, M. Cell type-specific responses of peripheral blood mononuclear cells to silver nanoparticles. Acta Biomater. 2011, 7, 3505-3514. [CrossRef]

69. Cao, H.; Liu, X.; Meng, F.; Chu, P.K. Biological actions of silver nanoparticles embedded in titanium controlled by micro-galvanic effects. Biomaterials 2011, 32, 693-705. [CrossRef]

70. Liao, C.; Li, Y.; Tjong, S.C. Bactericidal and cytotoxic properties of silver nanoparticles. Int. J. Mol. Sci. 2019, 20, 449. [CrossRef]

71. Wekwejt, M.; Michno, A.; Truchan, K.; Pałubicka, A.; Świeczko-Żurek, B.; Osyczka, A.M.; Zieliński, A. Antibacterial Activity and Cytocompatibility of Bone Cement Enriched with Antibiotic, Nanosilver, and Nanocopper for Bone Regeneration. Nanomaterials 2019, 9, 1114. [CrossRef]

72. Tang, J.C.; Luo, J.P.; Huang, Y.J.; Sun, J.F.; Zhu, Z.; Xu, J.; Dargusch, M.S.; Yan, M. Immunological response triggered by metallic 3D printing powders. Addit. Manufact. 2020, 35, 101392. [CrossRef]

73. Ginting, B.; Maulana, I.; Karnila, I. Biosynthesis copper nanoparticles using blumea balsamifera leaf extracts: Characterization of its antioxidant and cytotoxicity activities. Surf. Interfaces 2020, 21, 100799. [CrossRef]

74. Ismail, N.A.; Shameli, K.; Wong, M.M.-T.; Teow, S.-Y.; Chew, J.; Sukri, S.N.A.M. Antibacterial and cytotoxic effect of honey mediated copper nanoparticles synthesized using ultrasonic assistance. Mater. Sci. Eng. C 2019, 104, 109899. [CrossRef]

75. Poornavaishnavi, C.; Gowthami, R.; Srikanth, K.; Bramhachari, P.V. Nickel nanoparticles induces cytotoxicity, cell morphology and oxidative stress in bluegill sunfish (BF-2) cells. Appl. Surf. Sci. 2019, 483, 1174-1181. [CrossRef]

76. Lu, X.; Bao, X.; Huang, Y.; Qu, Y.; Lu, H.; Lu, Z. Mechanisms of cytotoxicity of nickel ions based on gene expression profiles. Biomaterials 2009, 30, 141-148. [CrossRef]

77. Marciano, F.R.; Bonetti, L.F.; Mangolin, J.F.; Da-Silva, N.S.; Corat, E.J.; Trava-Airoldi, V.J. Investigation into the antibacterial property and bacterial adhesion of diamond-like carbon films. Vacuum 2011, 85, 662-666. [CrossRef] 
78. Liu, C.; Zhao, Q.; Liu, Y.; Wang, S.; Abel, E.W. Reduction of bacterial adhesion on modified DLC coatings. Coll. Surf. B Biointerfaces 2008, 61, 182-187. [CrossRef]

79. Wang, H.; Tang, B.; Li, X.; Fan, A. Bacteria adherence properties of nitrogen-doped $\mathrm{TiO}_{2}$ coatings by plasma surface alloying technique. Phys. Procedia 2012, 32, 401-407. [CrossRef]

80. De Santis, R.; Mollica, F.; Ambrosio, L.; Ronca, D. Dynamic mechanical behaviour of PMMA based bone cements in the environment. J. Mater. Sci. Mater. Medic. 2003, 14, 583-594. [CrossRef]

81. Kolczyk, E.; Balin, A.; Kusz, D.; Sobczyk, K. Assessment of the tendency to aging of polymer bone cement. Eng. Biomater. 2010, 96-98, 4-9.

82. Balin, A. Cements in Bone Surgery; Silesian University of Technology: Gliwice, Poland, 2016.

83. Mousa, W.F.; Kobayashi, M.; Shinzato, S.; Kamimura, M.; Neo, M.; Yoshihara, S.; Nakamura, T. Biological and mechanical properties of PMMA-based bioactive bone cements. Biomaterials 2000, 21, 2137-2146. [CrossRef]

84. Toborek, J.; Gajda, Z.; Balin, A. Influence of the organism's environment on the bacteriostatic and mechanical properties of Palacos R cement with an antibiotic admixture. Orthop. Surg. 2002, 67, 605-611.

85. Colombi, P. Fatigue analysis of cemented hip prosthesis: Damage accumulation scenario and sensitivity analysis. Int. J. Fatigue 2002, 24, 739-746. [CrossRef]

86. Graham, J.; Pruitt, L.; Ries, M.; Gundian, N. Fracture and fatigue properties of acrylic bone cement. J. Arthroplast. 2000, 15, 1028-1035. [CrossRef]

87. Grasa, J.; Perez, M.; Bea, J.; Garcia-Aznar, J.; Doblare, M. A probabilistic damage model for acrylic cements. Application to the life prediction of cemented hip implants. Int. J. Fatigue 2005, 27, 891-904. [CrossRef]

88. Ishihara, S.; McEvily, A.; Goshima, T.; Konekasus, K.; Nara, T. On fatigue life time and fatigue crack growth behaviour of bone cement. J. Mater. Sci. Mater. Med. 2000, 11, 661-666. [CrossRef]

89. Lewis, G.; Mladsi, S. Correlation between impact strength and fracture toughness of PMMA- based bone cements. Biomaterials 2000, 21, 775-781. [CrossRef]

90. Kolczyk, E. Durability of Polymer Cement for Use in Orthopedics. Ph.D. Thesis, Silesian University, Katowice, Poland, 2010.

91. Heller Heller, M.; Bergmann, G.; Kassi, J.; Hass, N.; Duda, G. Determination of muscle loading at the hip joint for use in pre-clinical testing. J. Biomech. 2005, 38, 1155-1163. [CrossRef]

92. AshaRani, P.V.; Low Kah Mun, G.; Hande, M.P.; Valiyaveettil, S. Cytotoxicity and Genotoxicity of Silver Nanoparticles in Human Cells. ACS Nano 2009, 3, 279-290. [CrossRef]

93. Łukaszczyk, J. Polymer and composite bone cements and related materials. Polymers (Polimery) 2004, 44, 79-88.

94. Chen, L.; Tang, Y.; Zhao, K.; Zha, X.; Liu, J.; Bai, H.; Wu, Z. Fabrication of the antibiotic-releasing gelatin/PMMA bone cement. Coll. Surf. B Biointerfaces 2019, 183, 110448. [CrossRef]

95. Souza, T.A.J.; Franchi, L.P.; Rosa, L.R.; da Veiga, M.A.M.S.; Takahashi, C.S. Cytotoxicity and genotoxicity of silver nanoparticles of different sizes in CHO-K1 and CHO-XRS5 cell lines. Mutat. Res. Toxicol. Environ. Mutagen. 2016, 795, 70-83. [CrossRef]

96. Bartmański, M.; Pawłowski, Ł.; Mielewczyk-Gryń, A.; Strugała, G.; Rokosz, K.; Gaiaschi, S.; Chapon, P.; Raaen, S.; Zieliński, A. The influence of nanometals, dispersed in the electrophoretic nanohydroxyapatite coatings on the Ti13Zr13Nb alloy, on their morphology and mechanical properties. Materials 2021, 14, 1638. [CrossRef] 